Asian Pacific Journal of Reproduction

Journal homepage: www.apjr.net

\title{
Effect of epidermal growth factor on buffalo frozen spermatozoa biometry and metabolic activity
}

\author{
Mohamed MM Kandiel ${ }^{1 \bowtie}$, Ahmed RM El-Khawagah ${ }^{1}$, Karima Gh Mahmoud ${ }^{2}$ \\ ${ }^{\prime}$ Department of Theriogenology, Faculty of Veterinary Medicine, Benha University, Egypt \\ ${ }^{2}$ Department of Animal Reproduction and Artificial Insemination, National Research Centre, Dokki, Giza, Egypt
}

\section{ARTICLE INFO}

Article history:

Received 15 October 2016

Revision 20 November 2016

Accepted 22 November 2016

Available online 1 January 2017

\section{Keywords:}

Buffalo

Epidermal growth factor

Lipid peroxidation

Seminal enzymes

Speriogram

\begin{abstract}
Objective: To assess the effects of epidermal growth factor (EGF) on the Egyptian buffalo bull frozen semen, EGF was incorporated at 0 (control), 50, 100, 200 and $400 \mathrm{ng} / \mathrm{mL}$ of extender (Bioxcell®). Methods: Semen features, spermatozoa biometry, total liberated amounts of enzymes (aspartate transaminase, alanine aminotransferase, lactate dehydrogenase, acid phosphatase and alkaline phosphatase) and lipid peroxidation markers (thiobarbituric acid reactive substances, malondialdehyde, glutathione peroxidase, nitric oxide, catalase (CAT) and superoxide dismutase (SOD)) were determined in the spermatozoa-free extracellular extender. Results: Spermatozoa membrane integrity significantly $(P<0.05)$ increased, but DNA integrity decreased with EGF $200 \mathrm{ng} / \mathrm{mL}$. Spermatozoa head (dimensions, area and perimeter), but not shape, as well as acrosome and midpiece measures substantially differed with regard to EGF. Principle piece length and volume markedly decreased (at 100 and $200 \mathrm{ng} / \mathrm{mL}$ ), while total tail/flagellum length increased (at $50 \mathrm{ng} / \mathrm{mL}$ ) after EGF supplementation. EGF $50 \mathrm{ng} / \mathrm{mL}$ was associated with the decline of nitric oxide levels and catalase enzyme activity, but EGF 100 $\mathrm{ng} / \mathrm{mL}$ significantly decreased the total liberated amounts of enzymes (aspartate transaminase, lactate dehydrogenase, acid phosphatase and alkaline phosphatase) as well as lipid peroxidation markers (thiobarbituric acid reactive substances and malondialdehyde). Conclusions: EGF in vitro supplementation would affect the semen characteristics of buffalo bull with $100 \mathrm{ng} / \mathrm{mL}$ counteracted the freezing mediated oxidative stress indicated with the lowest enzymes leakage and lipid peroxidation.
\end{abstract}

\section{Introduction}

Efforts to improve the preservation of bull semen are focused on the modification of extenders[1], as well as on the implementation of various bio-active ingredients to maintain the activity and fertilizing capacity, and preserve the spermatozoa membrane integrity[2].

Epidermal growth factor (EGF), a polypeptide cytokine comprising 53 amino acid residues, was originally isolated and purified from the submandibular glands[3]. In males, EGF is produced by the Leydig (the principal source) and germ cells in the testes on attainment of

\footnotetext{
Corresponding author: Mohamed MM Kandiel, Department of Theriogenology, Faculty of Veterinary Medicine, Benha University, 13736, Toukh, Qaluobia, Egypt.

Tel: (+2013) 2461-411

Fax: (+2013) 2460-640

E-mail: moahmed.kandil@fvtm.bu.edu.eg; kandiel75@hotmail.com
}

the maturity, and may modulate spermatogenesis as an autocrine and/or paracrine factor[4].

Few data are available addressing the effect of EGF in vitro on semen characteristics. The published data showed that EGF effects on the functions of ejaculated spermatozoa are dependent on EGF concentration and animal species. Lax et al.[5] verified the effect of EGF in inducing the occurrence of the acrosomal reaction in bovine spermatozoa in a dose-dependent manner. Špalekovà et al.[6] noted

This is an open access article distributed under the terms of the Creative Commons Attribution-Non Commercial-Share Alike 3.0 License, which allows others to remix, tweak and buid upon the work non-commercially, as long as the author is credited and the new creations are licensed under the identical terms.

For reprints contact: reprints@medknow.com

(C2017 Asian Pacific Journal of Reproduction Produced by Wolters Kluwer- Medknow

How to cite this article: Mohamed MM Kandiel, Ahmed RM El-Khawagah, Karima Gh Mahmoud. Effect of epidermal growth factor on buffalo frozen spermatozoa biometry and metabolic activity. Asian Pac J Reprod 2017; 6(1): 43-48. 
that the effect of EGF on ram spermatozoa motility parameters was relied on its level and exposure time. In boar, EGF at 10 and $100 \mathrm{ng}$ / $\mathrm{mL}$ significantly improved the parameters of spermatozoa movement without affecting acrosome status, membrane integrity or motility either in intact or acrosome reaction-induced spermatozoa[7].

Cryopreservation encourages widespread biophysical and biochemical alterations in the membrane of spermatozoa due to its contents of various unsaturated fatty acids that ultimately decrease the fertility potential of the cells[8]. Cooling and thawing of spermatozoa resulted in the generation of superoxide radicals and nitric oxide[9]. In goats, Chauhan et al.[10] found a positive correlation between the leakage of spermatozoa enzymes (glutamic oxaloacetic transaminase, glutamate pyruvate transaminase, hyaluronoglucosaminidase, and acid and alkaline phosphatases) and acrosomal damage during dilution, cooling and freezing.

To the authors' knowledge, there are no previous studies entailed the impact of EGF on bull spermatozoa in vitro. Therefore, the current study aimed to assess the alternation in Egyptian buffalo bull frozen semen activity, spermatozoa biometry, DNA integrity, spermatozoa enzymes leakage and lipid peroxidation.

\section{Material and methods}

This study was conducted according to the principles expressed in the Declaration of Helsinki and approved by the The Committee on Graduate Studies and Research, Faculty of Veterinary Medicine, Benha University. Informed written consent was obtained from 2016.

\subsection{Semen collection, processing and evaluation}

Three proven fertile Egyptian buffalo bulls, kept in the Faculty Educational Farm, Benha University, aged between 3.5 and 6.5 years, were used during the period from January to April, 2016. Two ejaculates were collected from each bull once weekly with the bovine artificial vagina (Ref. 005417, IMV, France) adjusted at $(45.0 \pm 2.0){ }^{\circ} \mathrm{C}$ for twelve consecutive weeks.

After semen sampling, spermatozoa progressive motility (at 400 $\times$ ), concentration (by Neubauer haemocytometer) and normality were verified prior to semen processing. Samples possessed the minimal macroscopic and microscopic good quality standards (concentration $\geqslant 800 \times 10^{6} / \mathrm{mL}$, and motility as well as normality $\geqslant 70 \%$ ) were pooled and placed in a warm water bath (at $37{ }^{\circ} \mathrm{C}$ ) for cryo-processing.

Semen samples were split into aliquots each of $1.0 \mathrm{~mL}$, diluted with Bioxcell@ extender (IMV, France), according to manufacturer's instructions, and supplemented with EGF (E1257, Sigma-Aldrich, Germany) at different concentrations in triplicates: 0 (control), 50, 100,200 and $400 \mathrm{ng} / \mathrm{mL}$. Extended semen $\left(50 \pm 5 \times 10^{6}\right.$ spermatozoa $\left.\mathrm{mL}\right)$ was slowly cooled (within $1.0-1.5 \mathrm{~h}$ ) to $5{ }^{\circ} \mathrm{C}$, packed into $0.5 \mathrm{~mL}$ polyvinyl straws (Minitub, Germany) and equilibrated for (3-5) h. Freezing was accomplished at $\sim 4 \mathrm{~cm}$ above the liquid nitrogen level for $10 \mathrm{~min}$.

At $24 \mathrm{~h}$ post-storage in $\mathrm{N}_{2}$, Straws ( $n=4 /$ trial/treatment) were evaluated hourly post-thawing in a water bath at $\sim 37^{\circ} \mathrm{C}$ for $30 \mathrm{~s}$. The viability index was calculated according to Milovanov[11] to be equal to half of the post-thaw motility in addition to the summation of recorded motility at $1 \mathrm{~h}, 2 \mathrm{~h}$ and $3 \mathrm{~h}$ post-thawing.

Spermatozoa plasma membrane integrity was determined by HOS assay (HOS solution consisted of sodium citrate $0.735 \mathrm{~g}$ and fructose $1.351 \mathrm{~g}$, dissolved in $100 \mathrm{~mL}$ distilled water) at $37{ }^{\circ} \mathrm{C}$ for $60 \mathrm{~min}$ and the percentage of swollen and/or curled spermatozoa were recorded as HOS positive[12]. Spermatozoa morphology was assessed by Eosin-Nigrosin stain according to Andrabi et al.[13].

\subsection{Evaluation of sperm DNA integrity by acridine orange stain}

Frozen semen was washed with $5 \mathrm{~mL}$ of phosphate buffered saline, centrifuged $(700 \times \mathrm{g})$ and the spermatozoa pellets were re-suspended in $0.5 \mathrm{~mL}$ of PBS. A small aliquot $(50 \mu \mathrm{L})$ of the spermatozoa suspension was glass smeared ( $n=$ three slides/sample), air dried and fixed overnight in Carnoy's solution (3 parts Methanol/1 part Acetic acid) according to Liu et al.[14]. Once rinsed and air dried, the slides were stained for 5 min with freshly prepared acridine orange (AO) stain (comprised of $1 \% \mathrm{AO}$ in distilled water $(10.0 \mathrm{~mL})$ added to a mixture of $0.1 \mathrm{M}$ citric acid $(40.0 \mathrm{~mL})$ and $0.3 \mathrm{M} \mathrm{Na}_{2} \mathrm{HPO}_{47} \mathrm{H}_{2} \mathrm{O}$ $(2.5 \mathrm{~mL})$. Dried slides were examined with a fluorescent microscope (Leitz, Germany; excitation of 450-490 nm). Spermatozoa with intact chromatin or DNA content showed green fluorescence. Those with an abnormal DNA content emitted fluorescence in a spectrum varying from yellow-green to red.

\subsection{Spermatozoa biometry assessment}

Spermatozoa images were randomly selected and photographed from Eosin-Nigrosin stained slides with the use of a Euromax microscope (Holland). Image J software (National Institutes of Health, USA) was used for the assessment of spermatozoa biometry parameters. The software was standardized against a decimal scale. Fifty normal spermatozoa were captured and evaluated per slide ( $n=4$ slides/treatment/trial). The units for measurement variables were micrometers $(\mu \mathrm{m})$ and the ratios were without units. Spermatozoa morphology was quantified in terms of the following morphological features.

\subsubsection{Head measures}

The length (L), width (W), base width (B), acrosomal cap length and width were measured. The head area $\left(\mu \mathrm{m}^{2}\right)$, Perimeter $(\mathrm{P})$, Ellipticity (e), Elongation (El), Head shape (HS), Shape factor-1 (Rugosity), Shape factor-2, Shape factor-3 (Regularity) were 
calculated according to Van Duijn[15] as follows:

$$
\begin{gathered}
\text { Area }(A)=1.05-0.081 \times B^{2}+0.64 \mathrm{~W} \times \mathrm{L} \\
\text { Perimeter }=[3 \times(\mathrm{L}+\mathrm{W})-((3 \mathrm{~L}+\mathrm{W})(\mathrm{L}+3 \mathrm{~W})] \\
\text { Ellipticity }=\mathrm{L} / \mathrm{W}
\end{gathered}
$$$$
\text { Elongation }=(\mathrm{L}-\mathrm{W}) \times(\mathrm{L}+\mathrm{W})
$$$$
\text { Head shape }=\mathrm{W} / \mathrm{L}
$$

$$
\text { Shape factor }-1(\mathrm{Sf} 1)=4 \pi \mathrm{A} / \mathrm{P}^{2}
$$

Shape factor- $2(\mathrm{Sf} 2)=\mathrm{Sf} 1 \times(\mathrm{L} / \mathrm{W})$

Shape factpr-3 $(\mathrm{Sf} 3)=[\pi(\mathrm{L} \times \mathrm{W}) / 4] / \mathrm{A}$

\subsubsection{Tail measures}

The midpiece width [proximal and distal $(\mu \mathrm{m})]$ and length $(\mu \mathrm{m})$, principal piece length $(\mu \mathrm{m})$, terminal piece length $(\mu \mathrm{m})$, and flagellum length $(\mu \mathrm{m})$ were assessed. The midpiece, principal piece and total flagellum volumes $\left(\mu \mathrm{m}^{3}\right)$ were calculated according to RosSantaella et al.[16].

$$
\text { Midpiece volume }\left(\mu \mathrm{m}^{3}\right)=[\pi \times \mathrm{L} / 3] \times\left(\mathrm{R}^{2}+\mathrm{r}^{2}+\mathrm{R} \times \mathrm{r}\right)
$$

Where $L$ is the length of the midpiece. $R$ is the half proximal midpiece width. $\mathrm{r}$ is the half distal midpiece width.

$$
\text { Principal piece volume }\left(\mu \mathrm{m}^{3}\right)=\left(\pi \times \mathrm{R}^{2} \times \mathrm{L}\right) / 3
$$

Where $\mathrm{R}$ is the half midpiece width (i.e. Proximal or distal) and $\mathrm{L}$ is the length of the flagellum of the principle piece

$$
\text { Total flagellum volume }\left(\mu \mathrm{m}^{3}\right)=\left(\pi \times \mathrm{R}^{2} \times \mathrm{L}\right) / 3
$$

Where $\mathrm{R}$ is the half midpiece width (i.e. Proximal or distal) and $\mathrm{L}$ is the length of the flagellum of the principle plus terminal piece

\subsection{Extracellular enzymatic activity measurement}

Frozen thawed semen samples were centrifuged at $1000 \mathrm{~g}$ for 20 min. The supernatant fluid was collected and kept at $-20{ }^{\circ} \mathrm{C}$ until analysis. The activity of AST and ALT enzymes was determined with QCA kits (Amposta, Spain). The activity of ACP, ALP and LDH enzymes was assayed with Stanbio kits (Texas, USA) spectrophotometrically.

\subsection{Semen lipid peroxidation measurement}

Thiobarbituric acid reactive substances (TBARS) were estimated with TBARS Assay kit (Cayman Chemical Co., Ann Arbor, MI, USA) according to Armstrong et al.[17]. Malondialdehyde (MDA) production was measured according to Placer et al.[18]. Glutathione peroxidase (GPX) activity was determined by GPX commercial kit (Cayman Chemical Co., Ann Arbor, MI, USA) according to Paglia et al.[19]. Superoxide dismutase (SOD) activity was determined by SOD Assay kit (Cayman Chemical Co., Ann Arbor, MI, USA) according to Marklund et al.[20].

The Catalase (CAT) activity was measured according to the method of Goth[21]. Briefly, $0.3 \mathrm{~mL}$ of frozen-thawed semen was incubated in $1.7 \mathrm{~mL}$ of substrate $(65 \mu \mathrm{M}$ hydrogen peroxide in $50 \mathrm{mM}$ PBS, $\mathrm{pH} 7.0)$ at $37.5{ }^{\circ} \mathrm{C}$ for $60 \mathrm{~s}$. The enzymatic reaction was terminated with $1.0 \mathrm{~mL}$ of $32.4 \mathrm{mM}$ ammonium molybdate. The hydrogen peroxide was measured spectrophotometerically at $405 \mathrm{~nm}$ against control. The value of CAT activity was expressed as units (U) per milliliter (mL).

Nitric oxide (NO) concentration was assessed by monitoring the concentration of stable oxidation products of $\mathrm{NO}$ metabolites $\left(\mathrm{NO}_{2}-\mathrm{NO}_{3}-\right)$. Nitrite was determined using the Griess reaction by adding $1 \%$ sulfanilamide and $0.1 \%$ naphthylethylenediamine dihydrochloride in $2 \%$ phosphoric and incubation at $37{ }^{\circ} \mathrm{C}$ in the dark acid for $10 \mathrm{~min}$. The absorbance was recorded at $540 \mathrm{~nm}$ with a spectrophotometer. Nitrate was detected after reduction to nitrite using nitrate reductase as described elsewhere[22].

\subsection{Statistical analysis}

The data were analyzed and presented as mean \pm SE with oneway analysis of variance (ANOVA) using SPSS (Ver. 16). Multiple comparisons of the means were done with Dunnett's test. $P$ value was set at $<0.05$ to define statistical significance.

\section{Results}

\subsection{Semen characteristics and spermatozoa biometry}

Plasma membrane $(P<0.05)$ and DNA $(P=0.07)$ integrity of frozenthawed spermatozoa clearly differed in association with EGF supplementation. There was a decrease in membrane integrity with $50 \mathrm{ng} / \mathrm{mL}$, and DNA integrity with 50 and $200 \mathrm{ng} / \mathrm{mL}$ of EGF in respect to control. Other semen features (spermatozoa post-thawing motility, normality and viability index) differed numerically with the addition of EGF (Table 1).

Investigation of spermatozoa head biometry revealed considerable differences with EGF, with special emphasis to head length $(P<0.001)$ and width $(P<0.05)$, area $(P<0.001)$ and perimeter $(P<0.001)$ as well as acrosomal length $(P<0.001)$ and width $(P<0.005)$ as demonstrated in Table 2 . The highest measures were recorded with EGF $50 \mathrm{ng} / \mathrm{mL}$. In the meantime, EGF $100 \mathrm{ng} / \mathrm{mL}$ was associated with the lowest above mentioned measures.

Spermatozoa tail biometry showed substantial differences with EGF-exposure level, with special concern to the mid-piece (proximal end width, length and volume), the principal piece (length and volume) and consequently the total tail length and volume (Table 3 ). There was a marked $(P<0.001)$ decrease in midpiece proximal end width at high levels of EGF (100-400 ng/mL), and principle piece length and volume at EGF 100 and $200 \mathrm{ng} / \mathrm{mL}$. Nevertheless, midpiece length 
was significantly $(P<0.001)$ longer at EGF 50-400 levels, and the total tail/flagellum length was the longest $(P<0.005)$ at EGF $50 \mathrm{ng} / \mathrm{mL}$.

\subsection{Biochemical assay}

\subsubsection{Extracellular enzymatic activity}

An assessment of extracellular enzymatic activity in extended semen revealed substantial differences after inclusion of EGF in buffalo semen extender (Table 4). A noticeable decrease in the extracellular leaked AST $(P<0.01)$, ALP $(P<0.05)$, ACP $(P<0.05)$ and $\mathrm{LDH}(P<0.01)$ had been found with inclusions of EGF at $100 \mathrm{ng} / \mathrm{mL}$ level.

\subsubsection{Lipid peroxidation}

An assessment of lipid peroxidation indicators revealed clear differences in response to the enclosure of EGF in buffalo semen extender (Table 4). A significant $(P<0.01)$ decrease in TBARS and MDA at $100 \mathrm{ng} / \mathrm{mL}, \mathrm{CAT}$ and $\mathrm{NO}$ at 50 and $200 \mathrm{ng} / \mathrm{mL}$, and SOD at $400 \mathrm{ng} / \mathrm{mL}$ of EGF. Nevertheless, SOD increased markedly with EGF $50 \mathrm{ng} / \mathrm{mL}$.

\section{Discussion}

EGF has been detected in the male reproductive system and seminal plasma. It may contribute in male reproductive physiology by motivating the meiotic phase of spermatogenesis[23] and male fertility[24]. The current study highlighted the imminent impact of EGF in vitro on semen characteristics, lipid peroxidation and extracellular enzymes' activity in the cryopreserved buffalo semen.

In the present data, EGF supplementation in buffalo semen extender significantly altered plasma membrane and DNA integrity, though it did not influence spermatozoa motility, morphology and viability index. Furthermore, spermatozoa heads (head length and width, acrosomal length and width, spermatozoa head area and perimeter) as well as tails (midpiece width and length, principle

Table 1

The effect of epidermal growth factor on buffalo frozen semen characteristics.

\begin{tabular}{|c|c|c|c|c|c|c|c|}
\hline Group & $\begin{array}{c}\text { Plasma membrane } \\
\text { integrity }(\%)\end{array}$ & DNA integrity (\%) & $\begin{array}{l}\text { Post-thawing } \\
\text { motility }(\%)\end{array}$ & Sperm normality (\%) & Head Abnormality (\%) & Tail Abnormality (\%) & $\begin{array}{c}\text { Sperm Viability } \\
\text { Index }\end{array}$ \\
\hline Control & $70.25 \pm 3.92$ & $92.67 \pm 4.33$ & $38.75 \pm 7.74$ & $84.75 \pm 3.54$ & $1.00 \pm 0.58$ & $14.25 \pm 3.01$ & $53.63 \pm 14.28$ \\
\hline EGF 50 & $60.75 \pm 2.63^{*}$ & $83.25 \pm 1.38^{*}$ & $52.50 \pm 4.79$ & $75.00 \pm 4.49$ & $1.50 \pm 0.87$ & $23.50 \pm 5.24$ & $56.75 \pm 6.37$ \\
\hline EGF100 & $65.50 \pm 1.26$ & $85.50 \pm 2.22$ & $50.00 \pm 4.08$ & $81.00 \pm 2.16$ & $2.25 \pm 0.25$ & $16.75 \pm 2.32$ & $55.00 \pm 9.74$ \\
\hline EGF200 & $69.75 \pm 0.63$ & $83.33 \pm 2.60$ & $50.00 \pm 8.17$ & $81.25 \pm 1.11$ & $0.75 \pm 0.48$ & $18.00 \pm 1.47$ & $62.50 \pm 12.22$ \\
\hline EGF400 & $72.25 \pm 1.55$ & $89.67 \pm 0.88$ & $36.25 \pm 2.39$ & $84.75 \pm 2.18$ & $0.75 \pm 0.48$ & $14.50 \pm 2.06$ & $39.88 \pm 6.33$ \\
\hline$F$ value & $3.963^{\mathrm{ns}}$ & $2.757^{\mathrm{ns}}$ & $1.605^{\mathrm{ns}}$ & $1.833^{\mathrm{ns}}$ & $1.266^{\mathrm{ns}}$ & $1.458^{\mathrm{ns}}$ & $0.661^{\mathrm{ns}}$ \\
\hline$P$ value & $<0.05$ & 0.07 & 0.23 & 0.18 & 0.33 & 0.26 & 0.63 \\
\hline
\end{tabular}

Data are presented as mean \pm SE. ${ }^{*} P<0.05$ with the control group. ${ }^{\text {ns }} F$ value is not significant $P>0.05$.

Table 2

The effect of epidermal growth factor on the buffalo sperm head biometry.

\begin{tabular}{|c|c|c|c|c|c|c|c|c|c|c|c|c|c|}
\hline Group & $\begin{array}{l}\text { Sperm Head } \\
\text { Length }(\mu \mathrm{m})\end{array}$ & $\begin{array}{c}\text { Sperm Head } \\
\text { width }(\mu \mathrm{m})\end{array}$ & $\begin{array}{l}\text { Sperm Head } \\
\text { base }(\mu \mathrm{m})\end{array}$ & $\begin{array}{c}\text { Acrosome } \\
\text { length }(\mu \mathrm{m})\end{array}$ & $\begin{array}{l}\text { Acrosome } \\
\text { width }(\mu \mathrm{m})\end{array}$ & $\begin{array}{l}\text { Sperm Head } \\
\text { Area }\left(\mu \mathrm{m}^{2}\right)\end{array}$ & $\begin{array}{c}\text { Sperm Head } \\
\text { Perimeter }(\mu \mathrm{m})\end{array}$ & Ellipticity & Elongation & Head shape & $\begin{array}{l}\text { Shape } \\
\text { factor-1 }\end{array}$ & $\begin{array}{l}\text { Shape } \\
\text { factor-2 }\end{array}$ & $\begin{array}{l}\text { Shape } \\
\text { factor-3 }\end{array}$ \\
\hline Control & $8.33 \pm 0.10$ & $4.48 \pm 0.05$ & $1.62 \pm 0.05$ & $5.23 \pm 0.08$ & $4.34 \pm 0.06$ & $29.66 \pm 0.50$ & $41.18 \pm 0.38$ & $1.87 \pm 0.03$ & $0.299 \pm 0.007$ & $0.543 \pm 0.008$ & $0.219 \pm 0.002$ & $0.408 \pm 0.004$ & $0.989 \pm 0.002$ \\
\hline EGF50 & $8.38 \pm 0.09$ & $4.56 \pm 0.06$ & $1.64 \pm 0.07$ & $5.17 \pm 0.09$ & $4.37 \pm 0.08$ & $30.37 \pm 0.55$ & $41.55 \pm 0.39$ & $1.85 \pm 0.03$ & $0.294 \pm 0.007$ & $0.548 \pm 0.008$ & $0.220 \pm 0.001$ & $0.405 \pm 0.004$ & $0.990 \pm 0.003$ \\
\hline EGF100 & $7.70 \pm 0.12^{\text {temen }}$ & $4.23 \pm 0.07^{*}$ & $1.52 \pm 0.06$ & $4.58+0.11$ & $4.01 \pm 0.07^{\text {*** }}$ & $25.88 \pm 0.60^{\text {tomente }}$ & $38.31 \pm 0.47^{\text {malax }}$ & $1.83 \pm 0.04$ & $0.292 \pm 0.01$ & $0.553 \pm 0.012$ & $0.221 \pm 0.002$ & $0.403 \pm 0.006$ & $0.989 \pm 0.003$ \\
\hline EGF200 & $7.98 \pm 0.08^{*}$ & $4.35 \pm 0.06$ & $1.54 \pm 0.06$ & $4.77 \pm 0.08^{\text {insolem }}$ & $4.13 \pm 0.06$ & $27.57 \pm 0.50^{*}$ & $39.60 \pm 0.36^{*}$ & $1.84 \pm 0.03$ & $0.297 \pm 0.01$ & $0.548 \pm 0.009$ & $0.220 \pm 0.002$ & $0.405 \pm 0.004$ & $0.991 \pm 0.003$ \\
\hline EGF400 & $8.04 \pm 0.12$ & $4.44 \pm 0.13$ & $1.45 \pm 0.05$ & $4.86 \pm 0.09^{* * *}$ & $4.24 \pm 0.05$ & $27.79 \pm 0.51^{*}$ & $40.11 \pm 0.38$ & $1.87 \pm 0.05$ & $0305 \pm 0.008$ & $0.571 \pm 0.037$ & $0.217 \pm 0.002$ & $0.402+0.008$ & $0.995 \pm 0.003$ \\
\hline$F$ value & $6.449^{\mathrm{ns}}$ & $2.481^{\mathrm{ns}}$ & $1.611^{\mathrm{ns}}$ & $8.973^{\mathrm{ns}}$ & $4.129^{\mathrm{ns}}$ & $9.836^{\mathrm{ns}}$ & $9.105^{\mathrm{ns}}$ & $0.901^{\mathrm{ns}}$ & $0.187^{\mathrm{ns}}$ & $0.458^{\mathrm{ns}}$ & $0.421^{\mathrm{ns}}$ & $0.901^{\mathrm{ns}}$ & $0.205^{\mathrm{ns}}$ \\
\hline
\end{tabular}

Data are presented as mean \pm SE. ${ }^{*} P<0.05,{ }^{* *} P<0.01,{ }^{* * * *} P<0.0001$ with the control group. ${ }^{\text {ns }} F$ value is not significant $P>0.05$.

Table 3

The effect of epidermal growth factor on buffalo sperm tail biometry.

\begin{tabular}{|c|c|c|c|c|c|c|c|c|c|}
\hline Group & $\begin{array}{c}\text { Midpiece width, } \\
\text { proximal }(\mu \mathrm{m})\end{array}$ & $\begin{array}{l}\text { Midpiece width, } \\
\text { distal }(\mu \mathrm{m})\end{array}$ & $\begin{array}{c}\text { Midpiece } \\
\text { length }(\mu \mathrm{m})\end{array}$ & $\begin{array}{c}\text { Principle piece } \\
\text { length }(\mu \mathrm{m})\end{array}$ & $\begin{array}{c}\text { Terminal piece } \\
\text { length }(\mu \mathrm{m})\end{array}$ & $\begin{array}{c}\text { Total Flagellum } \\
\text { length }(\mu \mathrm{m})\end{array}$ & $\begin{array}{c}\text { Midpiece } \\
\text { volume }\left(\mu \mathrm{m}^{3}\right)\end{array}$ & $\begin{array}{l}\text { Principal piece } \\
\text { volume }\left(\mu \mathrm{m}^{3}\right)\end{array}$ & $\begin{array}{l}\text { Total flagellum } \\
\text { volume }\left(\mu \mathrm{m}^{3}\right)\end{array}$ \\
\hline Control & $1.05 \pm 0.03$ & $0.77 \pm 0.02$ & $10.49 \pm 0.25$ & $22.70 \pm 0.47$ & $5.34 \pm 0.20$ & $38.42 \pm 0.56$ & $13.92 \pm 0.82$ & $6.88 \pm 0.45$ & $11.69 \pm 0.81$ \\
\hline EGF50 & $1.04 \pm 0.03$ & $0.85 \pm 0.14$ & $12.14 \pm 0.35^{* *}$ & $23.06 \pm 0.47$ & $6.03 \pm 0.33$ & $41.22 \pm 0.60^{* * * *}$ & $19.26 \pm 0.90$ & $6.94 \pm 0.45$ & $12.53 \pm 0.81$ \\
\hline EGF100 & $0.93 \pm 0.04^{*}$ & $0.70 \pm 0.03$ & $12.53 \pm 0.55^{* *}$ & $20.17 \pm 0.60^{* * *}$ & $5.640 \pm 0.21$ & $38.35 \pm 0.87$ & $13.28 \pm 1.08$ & $4.83 \pm 0.38^{* * * *}$ & $9.14 \pm 0.71$ \\
\hline EGF200 & $0.85 \pm 0.04^{* * * *}$ & $0.75 \pm 0.17$ & $12.26 \pm 0.43^{* *}$ & $20.78 \pm 0.48^{* *}$ & $5.17 \pm 0.17$ & $38.22 \pm 0.73$ & $13.48 \pm 0.01$ & $4.32 \pm 0.40^{* * * *}$ & $7.88 \pm 0.71^{* * *}$ \\
\hline EGF 400 & $0.87 \pm 0.03^{* * * *}$ & $0.61 \pm 0.02$ & $12.12 \pm 0.41^{\text {*** }}$ & $22.65 \pm 0.46$ & $5.49 \pm 0.22$ & $40.26 \pm 0.68$ & $10.68 \pm 0.83$ & $4.65 \pm 0.31^{* * * *}$ & $8.29 \pm 0.54^{* * *}$ \\
\hline$F$ value & $8.245^{\mathrm{ns}}$ & $0.71^{\mathrm{ns}}$ & $5.486^{\mathrm{ns}}$ & $5.872^{\mathrm{ns}}$ & $1.906^{\mathrm{ns}}$ & $4.496^{\mathrm{ns}}$ & $1.606^{\mathrm{ns}}$ & $9.253^{\mathrm{ns}}$ & $7.591^{\mathrm{ns}}$ \\
\hline$P$ value & $<0.001$ & 0.586 & $<0.001$ & $<0.001$ & 0.110 & $<0.005$ & 0.173 & $<0.001$ & $<0.001$ \\
\hline
\end{tabular}

Data are presented as mean \pm SE. ${ }^{*} P<0.05,{ }^{* *} P<0.01,{ }^{* * * *} P<0.001,{ }^{* * * *} P<0.0001$ with the control group. ${ }^{\text {ns }} F$ value is not significant $P>0.05$ 
Table 4

Effect of epidermal growth factor on buffalo semen extra-cellular enzymatic activity (U/109 spermatozoa) and lipid peroxidation activity.

\begin{tabular}{|c|c|c|c|c|c|c|c|c|c|c|c|}
\hline Group & AST & ALT & ALP & $\mathrm{ACP}$ & $\mathrm{LDH}$ & $\begin{array}{c}\text { TBARS } \\
(\mathrm{nmol} / \mathrm{mL})\end{array}$ & $\begin{array}{c}\text { MDA } \\
(\mathrm{nmol} / \mathrm{mL})\end{array}$ & $\begin{array}{c}\text { GPX } \\
(\mathrm{U} / \mathrm{mL})\end{array}$ & $\begin{array}{c}\mathrm{NO} \\
(\mu \mathrm{mol} / \mathrm{mL})\end{array}$ & $\begin{array}{c}\text { CAT } \\
(\mathrm{U} / \mathrm{mL})\end{array}$ & $\begin{array}{c}\text { SOD } \\
(\mathrm{U} / \mathrm{mL})\end{array}$ \\
\hline Control & $69.10 \pm 6.57$ & $25.58 \pm 1.94$ & $803.67 \pm 15.90$ & $1.68 \pm 0.37$ & $83.71 \pm 7.47$ & $3.11 \pm 0.44$ & $27.26 \pm 4.62$ & $4.11 \pm 1.19$ & $36.64 \pm 2.74$ & $34.05 \pm 2.59$ & $12.09 \pm 1.34$ \\
\hline EGF 50 & $60.09 \pm 4.89$ & $21.02 \pm 1.80$ & $876.33 \pm 74.83$ & $2.53 \pm 0.21^{* *}$ & $64.76 \pm 6.19^{*}$ & $2.76 \pm 0.14$ & $42.67 \pm 1.98^{* * *}$ & $2.56 \pm 0.43$ & $23.91 \pm 2.42^{*}$ & $20.28 \pm 1.48^{*}$ & $24.41 \pm 2.95^{* *}$ \\
\hline EGF 200 & $53.12 \pm 5.27$ & $24.76 \pm 2.97$ & $838.67 \pm 54.11$ & $1.06 \pm 0.05^{*}$ & $62.88 \pm 6.36^{* *}$ & $1.72 \pm 0.12^{* *}$ & $29.87 \pm 4.21^{* *}$ & $3.64 \pm 0.31$ & $21.72 \pm 5.59^{*}$ & $20.86 \pm 1.99^{*}$ & $21.95 \pm 1.93^{*}$ \\
\hline EGF 400 & $56.41 \pm 5.40$ & $22.01 \pm 1.04$ & $965.00 \pm 31.43^{*}$ & $1.89 \pm 0.34$ & $37.43 \pm 3.63^{* * * *}$ & $2.20 \pm 0.30^{*}$ & $38.81 \pm 3.22^{*}$ & $2.88 \pm 0.28$ & $31.27 \pm 2.54$ & $37.49 \pm 3.66$ & $13.24 \pm 1.75$ \\
\hline$F$ value & $6.334^{\mathrm{ns}}$ & $1.021^{\mathrm{ns}}$ & $3.846^{\mathrm{ns}}$ & $6.771^{\mathrm{ns}}$ & $11.775^{\mathrm{ns}}$ & $10.122^{\mathrm{ns}}$ & $8.957^{\mathrm{ns}}$ & $1.582^{\mathrm{ns}}$ & $4.043^{\mathrm{ns}}$ & $8.287^{\mathrm{ns}}$ & $7.772^{\mathrm{ns}}$ \\
\hline$P$ value & $<0.01$ & 0.44 & $<0.05$ & $<0.01$ & $<0.01$ & $<0.01$ & $<0.01$ & 0.25 & $<0.05$ & $<0.01$ & $<0.01$ \\
\hline
\end{tabular}

Data are presented as mean \pm SE. AST: Aspartate transaminase, ALT: Alanine aminotransferase, ACP: Acid phosphatase, ALP: Alkaline phosphatase and LDH: Lactate dehydrogenase. TBARS: Thiobarbituric acid reactive substances, MDA: Malondialdehyde, GPX: Glutathione peroxidase enzyme, NO: Nitric oxide, CAT: Catalase enzyme, SOD: Superoxide dismutase enzyme. ${ }^{*} P<0.05,{ }^{* *} P<0.01,{ }^{* * * *} P<0.001$ with the control group. ${ }^{\text {ns }} F$ value is not significant $P>0.05$.

piece length and volume, and total tail length) were clearly differed with EGF levels as compared with control. The increase in midpiece volume may be decoded to greater swimming velocities and thus results in an advantage in spermatozoa competition[25]. These results suggested that EGF may have a role in spermatozoa morphological attributes. Former studies localized EGF receptors at higher extent in the acrosome region than to the post-acrosome and the flagellum[7]. Although no former studies verified the effect of EGF on frozen semen characteristics, fresh ram semen stored with EGF at $4{ }^{\circ} \mathrm{C}$ showed an enhanced motility, viability and membrane integrity[26]. EGF increased ram spermatozoa motility at all doses tested, especially when EGF was added to the spermatozoa after 2-day of storage. The increase in midpiece volume may be translated to greater swimming velocities and thus lead to an advantage in spermatozoa competition and consequently improve its fertilizing capacity[25]. EGF decreased the proportion of spermatozoa with damaged plasma membrane and apoptotic spermatozoa when given at 200 or $400 \mathrm{ng} / \mathrm{mL}[26]$. Low concentration (0.1-10 nM) of EGF had no effect on the percent of human spermatozoa motility, but higher concentrations ( $\geqslant 25 \mathrm{nM}$ ) significantly affected various spermatozoa motility characteristics, particularly velocity and amplitude of lateral head movement[27]. It is supposed that EGF effects are mediated via Ras or Rho components of ERK pathway, which are localized in the flagellum of bovine[28] and hamster[29] spermatozoa, and are involved in spermatozoa motility regulation. EGF at higher doses lowered the number of spermatozoa with PNA-labeled membrane, i.e. this growth factor can act as a membrane stabilizer[26].

Damage occurring to spermatozoa during the freezing-thawing procedures mostly affect spermatozoa's membranes (plasma and mitochondria) and in the worst case, the nucleus[30]. These injuries are most likely due to the formation of extra- and intracellular ice crystals and increasing solution concentration[31]. Cryopreservation of spermatozoa is associated with reactive oxygen species production and lipid peroxidation. This could harm spermatozoa membrane[32], causing spermatozoa pathology (ATP depletion) and insufficient axonemal protein phosphorylation leading to loss of motility and viability[33]. Based on recent literature, cellular cryodamage in reproductive cells has been extensively characterized in terms of changes in the cell structure, whereas biochemical variations have been fairly explored[32]. Investigation of the influence of EGF on spermatozoa biochemical features in terms of an extracellular enzymes' activity and lipid peroxidation markers showed considerable differences after inclusion of EGF in the buffalo semen extender, indicating that the EGF was able to inhibit the propagation of the peroxidative chain reaction. A noticeable decrease in AST, ALP, ACP and LDH, TBARS and MDA was noticed in extender supplemented with EGF at a level of $100 \mathrm{ng} / \mathrm{mL}$. Nevertheless, CAT and NO activities dropped upon EGF supplementation at the level of $50 \mathrm{ng} / \mathrm{mL}$ and $200 \mathrm{ng} / \mathrm{mL}$. SOD levels markedly $(P<0.01)$ reduced with EGF $400 \mathrm{ng} / \mathrm{mL}$, but elevated with EGF $50 \mathrm{ng} / \mathrm{mL}$. The antioxidant system in the cell is comprised of reduced glutathione, glutathione peroxidase (CAT and SOD)[34]. Natural antioxidant system and synthetic phenolic antioxidant butylated hydroxytoluene have been described as a defense functioning mechanism against lipid peroxidation in semen[35]. Supplementation with these antioxidants prior to the freezing procedures may be endorsed to improve spermatozoa the cryopreservation technique in the goat breeding industry[36].

In conclusion, EGF implemented in the extender of buffalo frozen semen affected the semen features and spermatozoa biometry. The supplementation of EGF at $50 \mathrm{ng} / \mathrm{mL}$ was associated with elongation of spermatozoa and an increase of the mid-piece size and/or volume, which is advantageous for better motility velocities and consequently its fertilizing capacity. EGF at the level of $100 \mathrm{ng} / \mathrm{mL}$ might have cryoprotective properties through its antioxidant activity as well as maintenance of the stability of the spermatozoa plasma membranes' lipid contents as indicated by the decrease in enzymes leakage and lipid peroxidation.

\section{Conflict of interest statement}

The authors declare that they have no conflict of interest. 


\section{References}

[1] Amirat L, Anton M, Tainturier D, Chatagnon G, Battut I, Courtens JL. Modifications of bull spermatozoa induced by three extenders: Biociphos, low density lipoprotein and Triladyl, before, during and after freezing and thawing. Reprod 2005; 129(4): 535-543.

[2] Elkhawagah AR, Longobardi V, Neglia G, Salzano A, Zullo G, Sosa GA, et al. Effect of relaxin on fertility parameters of frozen-thawed buffalo (Bubalus bubalis) sperm. Reprod Domest Anim 2015; 50(5): 756-762.

[3] Carpenter G, Cohen S. Epidermal growth factor. J Biol Chem 1990; 265(14): 7709-7712.

[4] Yan YC, Sun YP, Zhang ML. Testis epidermal growth factor and spermatogenesis. Arch Androl 1998; 40: 133-146.

[5] Lax Y, Rubinstein S, Breitbart H. Epidermal growth factor induces acrosomal exocytosis in bovine sperm. FEBS Lett 1994; 339: 234-238.

[6] Spalekova E, Makarevich AV, Lukác` N. Ram sperm motility parameters under the influence of epidermal growth factor. Vet Med Int 2011; 642931.

[7] Oliva-Hern'andez J, P'erez-Guti'errez JF. Localization of the epidermal growth factor (EGF) in the epididymis and accessory genital glands of the boar and functional effects on spermatozoa. Theriogenology 2008; 70(7): 1159-1169.

[8] Chatterjee S, de Lamirande E, Gagnon C. Cryopreservation alters membrane sulfhydryl status of bull spermatozoa: Protection by oxidized glutathione. Mol Reprod Dev 2001; 60(4): 498-506.

[9] Chatterjee S, Gagnon C. Production of reactive oxygen species by spermatozoa undergoing cooling, freezing and thawing. Mol Reprod Dev 2001; 59(4): 451-458

[10]Chauhan MS, Kapila R, Gandhi KK, Anand SR. Acrosome damage and enzyme leakage of goat spermatozoa during dilution, cooling and freezing. Andrologia 1994; 26(1): 21-26.

[11]Milovanov VK. Biology of reproduction and artificial insemination of farm animals. Moscow: Seljhozizdat; 1962, p. 696.

[12]Akhter S, Ansari MS, Andrabi SM, Ullah N, Qayyum M. Effect of antibiotics in extender on bacterial and spermatozoal quality of cooled buffalo (Bubalus bubalis) bull semen. Reprod Domest Anim 2008; 43(3): 272-278.

[13]Andrabi SM, Ansari MS, Ullah N, Anwar M, Mehmood A, Akhter S. Duck egg yolk in extender improves the freezability of buffalo bull spermatozoa. Anim Reprod Sci 2008; 104(2-4): 427-433.

[14]Liu DY, Baker HWG. A new test for the assessment of sperm-zona pellucida penetration: Relationship with results of other sperm tests and fertilization in vitro. Hum Reprod 1994; 9(3): 489-496.

[15]Van Duijn CJ. Mensuration of the heads of bull spermatozoa. Mikroskopie 1960; 14: 265-276.

[16]Ros-Santaella JL, Domínguez-Rebolledo ÁE, Garde JJ. Sperm flagellum volume determines freezability in red deer spermatozoa. PLoS ONE 2014; 9(11): e112382.

[17]Armstrong D, Browne R. The analysis of free radicals, lipid peroxides, antioxidant enzymes and compounds related to oxidative stress as applied to the clinical chemistry laboratory. Advanc Experiment Med Biol 1994;
366: $43-58$.

[18]Placer ZA, Cushman LL, Johnson BC. Estimation of product of lipid peroxidation (malonyldialdehyde) in biochemical systems. Anal Biochem 1966; 16(2): 359-364.

[19]Paglia DE, Valentine WN. Studies on the quantitative and qualitative characterization of erythrocyte glutathione peroxidase. J Lab Clinica Med 1967; 70(1): 158-169.

[20]Marklund SL, Holme E, Hellner L. Superoxide dismutase in extracellular fluids. Clinica Chimica Acta 1982; 126(1): 41-51.

[21]Goth L. A simple method for determination of serum CAT activity and revision of reference range. Clin Chim Acta 1991; 196(2-3): 143-151.

[22]Harad H, Schmiot H. Determination of nitric oxide via measurement of nitrite and nitrate in culture media. Biochemica 1995; 2: 22-23.

[23]Tsutsumi O, Kurachi H, Oka T. A physiological role of epidermal growth factor in male reproductive function. Science 1986; 233(4767): 975-977.

[24]Ahmad K, Naz RK. Role of epidermal growth factor in reproduction. Ass Reprod Tech Androl 1993; 4: 85-92.

[25]Anderson MJ, Dixson AF. Sperm competition: Motility and the midpiece in primates. Nature 2002; 416(6880): 496

[26]Makarevich AV, Spalekova E, Olexikova L, Lukac N, Kubovicova E, Hegedusova Z. Functional characteristics of ram cooling-stored spermatozoa under the influence of epidermal growth factor. Gen Physiol Biophys 2011; 30: 36-43.

[27]Naz RK, Kaplan P. Effects of epidermal growth factor on human sperm cell function. J Androl 1993; 14(4): 240-247.

[28]Fujita A, Nakamura K, Kato T, Watanabe N, Ishizaki T, Kimura K, et al. Ropporin, a sperm-specific binding protein of rophilin that is localized in the fibrous sheet of the sperm flagella. J Cell Sci 2000; 113: 103-112.

[29]Nag Das SK, Winfrey VP, Olson GE. Identification of Ras and its downstream signaling elements and their potential role in hamster sperm motility. Biol Reprod 2002; 67(4): 1058-1066.

[30]Blesbois E. Current status in avian semen cryopreservation. World' $s$ Poult Sci J 2007; 63: 213-222.

[31]Mazur P. Freezing of living cells: mechanisms and implications. Am J Physiol 1984; 247: 125-142.

[32]Tatone C, Di emidio G, Vento M, Rosanna Ciriminna R, Artini PG. Cryopreservation and oxidative stress in reproductive cells. Gynecol Endocrinol 2010; 26(8): 563-567.

[33]Bansal AK, Bilaspuri GS. Impacts of oxidative stress and antioxidants on semen functions. Vet Med Int 2011; pii: 686137.

[34]Marti J, Marti E, Cebrián-Pérez J, Muiño-Blanco T. Survival rate and antioxidant enzyme activity of ram spermatozoa after dilution with different extenders or selection by a dextran swim-up procedure Theriogenology 2003; 60(6): 1025-1037.

[35]Shoae A, Zamiri MJ. Effect of butylated hydroxytoluene on bull sperm frozen in egg yolk-citrate extender. Anim Reprod Sci 2008; 104(2-4): 414 418.

[36]Bucak MN, Sarızkan S, Tuncer PB, Sakin F, Atessahin A, Kulaksız $\mathrm{R}$, et al. The effect of antioxidants on post-thawed Angora goat (Capra hircus ancryrensis) sperm parameters, lipid peroxidation and antioxidant activities. Small Rum Res 2010; 89(1): 24-30. 